\title{
OPMERKINGE OOR DIE VERHOUDING: KERK EN KONINKRYK
}

\author{
PROF. DR. J. A. HEYNS
}

Enkele opmerkinge oor die verhouding van kerk en koninkryk is na my oordeel volkome ter sake in ' $n$ feesbundel soos hierdie waarmee ' $n$ kollega se arbeid van ' $n$ kwarteeu in die vak dogmatiek, in dankbare herinnering geroep word.

Interkerklike verhoudinge begin immers - teoreties altans by ' $n$ verantwoorde Skriftuurlike siening oor die kerk. Maar wie, vanuit die Skrif, oor die kerk wil gaan nadink, word verplig om die kerk in wyer en groter dimensies te gaan sien. En die grootste en wydste waarbinne die kerk geplaas kan en ook moet word, is dié van die koninkryk van God. Van dááruit kom die kerk as sodanig enigsins in die juiste perspektief te staan, en kan die eie kerk ook beter en juister beoordeel word. En dit kan op sy beurt kerklike verhoudinge stimuleer en suiwer.

Om met 'n omskrywing van die begrip koninkryk te begin:

Die koninkryk is Gods heerskappy oor en die gehoorsame aanvaarding daarvan deur sy onderdane: stof, plant, dier, mens en engele. Nog korter: die koninkryk is die triomf van Gods wil.

Enkele belangrike konklusies kan hieruit getrek word. Ten eerste: Die koninkryk van God is 'n universele werklikheid. Dit mag met ander woorde nie na die innerlikheid van die mens verplaas word en in ' $n$ mistieke gemeenskap van die mens met God opgaan nie. Ewe min mag dit alleen op die verlossing van die mens van toepassing gemaak word. Natuurlik het beide die spirituele en die soteriologiese ' $n$ plek in die koninkryk, maar lg. mag nie tot dié aspekte alléén gereduseer word nie. Die universaliteit van die koninkryk beteken ook dat nie net enkele van die mens se aktiwiteite nie maar letterlik alles wat hy doen by die koninkryk betrek is. Nie net sy kultiese handelinge in die kerk nie, maar ook sy rasionele handelinge in wetenskap en politiek, sy estetiese handelinge in letterkunde en drama, sy ontspanning in sport en spel - letterlik alles kan koninkrykshandelinge word, mits hy daar in gehoorsaamheid aan Gods Woord handel en optree. Nie net die mens nie, ook die natuur is aan Gods wetmatigheid onderworpe en waar dit gebeur, is iets van die koninkryk aanwesig. Ten tweede: Die koninkryk van God is 'n dinamiese werklikheid. Ons het nie met 'n statiese toestand nie, maar met ' $n$ dinamiese gebeure te doen. Die lewende God spreek voortdurend sy Woord en daardeur lei Hy sy Skepping van die oue na die nuwe, van die begin na die einde. Daar is ontwikkeling en vooruitgang, daar is verdieping en vermeerdering; daar is ' $n$ geskiedenis van die menslike handelinge. Ten derde: Die koninkryk van God is 'n teenwoordige én toekomstige werklikheid. Waar God 
heers en onderworpenheid aanwesig is, daar is die koninkryk. Maar juis omdat dit 'n dinamies-eskatologiese gebeure is, is daar ook ' $n$ intensiewe en ekstensiewe uitbreiding. Meer nog: die toekomstigheid van die koninkryk impliseer nie 'n blote reglynige maksimale ontwikkeling van latente moontlikhede nie, maar dui ook op 'n transendente ingryping van God. Daarom is die koninkryk nie net nie, maar kom hy ook. Die koninkryk van God is 'n werklikheid wat ook die kosmiese werklikheid insluit. Die koninkryk kan nie net met die heerskappy van God aangedui word nie. Dit sou eensydig wees. Dit gaan ook om die aanvaarding daarvan deur die skepping. God skakel die werk van sy hande in. Selfs waar Hy heers, gebruik Hy mense om gesag in sy Naam uit te oefen. Ten vierde: Die koninkryk van God is ' $n$ werklikheid wat ' $n$ teenwerklikheid ken. Die sonde is as sonde, dit wil sê as ongehoorsaamheid aan en verwerping van Gods heerskappy, nie deel van die Godsryk nie. En tog roep dit 'n ryk op - 'n ryk van boosheid en leuen, van haat en vernietiging; 'n anti-ryk dus wat die skepping verskeur en die gelowige met 'n anti-woord versoek. Daarom ken die koninkryk en die burgers van die koninkryk, antitese en spanning. Natuurlik is die spanning tussen die ryk van God en die ryk van die Bose nie 'n ewewigsverhouding nie. Dit is nie twee groothede van dieselfde omvang, duur en betekenis wat teenoor mekaar staan nie. Die ryk van die Bose parasiteer op die Godsryk; dit is die spreekwoordelike stok in die wiel van die koninkrykswa op weg na sy eindbestemming. Nie die Bose nie, maar God oorwin; hét oorwin en sal sy oorwinning eenmaal aan almal bekend maak. "Want uit Hom en deur Hom en tot Hom is alle dinge. Syne is die heerlikheid tot in ewigheid" (Rom. 11:36). Maar tot dan mag die Bose nie geignnoreer word nie, dog in die geloof weerstaan word.

Ná hierdie enkele opmerkinge oor die koninkryk, gee ons vervolgens aandag aan die begrip kerk.

In die kerk gaan dit om mense - mense wat as sondaars tot geloof in Jesus Christus gekom het, en wat deur Hom in 'n byeenkoms saamgebring word waar hulle na die amptelike verkondiging van die Woord luister en waar hulle hul nuutgevonde heil in kultiese handelinge belewe. Die basiese struktuur van die kerk kom dus hierop neer: enersyds God wat in genade mense in Jesus Christus uitverkies en roep en andersyds mense wat uit gehoorsaamheid instemming met Gods bedoeling betuig. Hierdie roeping en gelowige aanvaarding daarvan vind egter binne 'n gegewe en vaste struktuur plaas: die byeenkoms van kultiese handelinge onder amptelike leiding. Kulties wil in hierdie verband sê: handelinge wat spesiaal vir die doel van so 'n godsdienstige gebeure afgesonder en gebruik word. Geen enkele magiese betekenis word daaraan toegedig nie en van die res van die lewenshandelinge word hulle ook nie geisoleer nie. Inteendeel, die kultiese handelinge wys juis heen na 
alle ander handelinge, want dit onthul die geheim van die ganse lewe. Bybellesing en gebed, lied, offer en geloofsbelydenis, in 'n bepaalde orde mekaar opvolgend, is heilige handelinge, nie omdat dit kultiese handelinge is nie — dit sou magies wees - maar omdat dit die kultiese handelinge is van 'n volk deur God geroep en geregverdig - dus deur Hom ook geheilig. Hier word as't ware gedramatiseer wat die gelowiges van die ganse verbondslewe met God glo en daagliks ook as verbondsvolk van God moet doen.

Laat ons nou die antwoord op die vraag na die verhouding van kerk en koninkryk, eers by die negatiewe begin.

Koninkryk en kerk is nie identies nie. Die koninkryk mag nie tot die kerk beperk word nie - soos dit in die geskiedenis van die teologie al dikwels gebeur het. Die koninkryk is veel ruimer as die kerk en die kerk veel enger as die koninkryk. Maar dit is ook nie waar dat die twee chualisties naas mekaar staan en feitlik niks met mekaar te doen het nie, of, dat kerk en koninkryk selfs vyandig teenoor mekaar geplaas word soos in sommige apokaliptiese kringe gedoen word nie. Of dat kerk en koninkryk mekaar ewolusionisties só opvolg dat die koninkryk eers later by die voleinding 'n werklikheid sal word en die kerk tans alleen maar antisiperend daarop vooruitgryp. Misties is die verhouding ook nie. Die koninkryk mag nie só radikaal verinnerlik word dat dit uitein delik met God vereenselwig word, terwyl die kerk as die sigbare ruimte gesien word waar die rykdom van die innerlike bloot net belewe word nie. Die verhou ding tussen koninkryk en kerk is ewe min moralisties van aard. Die koninkryk is nie die deugvolle lewe met die goeie, die ware en die skone as die hoogste versiering en beste prestasie van die mens se lewe, terwyl die kerk hom, met Christus as voorbeeld, bloot net daartoe oproep en aanspoor nie.

Gaan ons nou oor tot die positiewe in die verhouding van koninkryk en kerk, wil ons begin deur te herhaal: die koninkryk is daar waar aan Gods heerskappy gehoor gegee word; waar stof, plant en dier hulle aan Gods heerskappy onderwerp en waar mense hulle in gehoorsaamheid daaraan gebonde weet. Gemaklikheidshalwe kan ons eersgenoemde die kosmiese en laasgenoemde die antroposentriese aspek van die koninkryk noem. Van direkte belang in die bepaling van die verhouding van koninkryk en kerk is uiteraard die antroposentriese omdat dit die gemeenskaplike in albei is.

Tot die koninkryk behoort alleen die burgers van die koninkryk en burgers is hulle wat uit die mag van die duisternis deur Christus verlos en in die koninkryk oorgebring is (Kol. 1:13). Teenoor hierdie burgers is daar ook die burgers van die ryk van die Bose - die sondaars wat nie (of nog nie) uit die mag van die duisternis gered is nie en wat onder Satan as hulle hoof lewe. Die burgers van die 
Godsryk aanvaar Gods heerskappy oor hul lewe en gehoorsaam Hom in alles wat hulle dink of sê of doen. Uitdruklik skrywe Paulus: .En wat julle ookal doen in woord of in daad, doen alles in die Naam van die Here Jesus en dank God die Vader deur Hom" (Kol. 3:17). Verder aan in dieselfde hoofstuk lees ons: "En wat julle ook al doen, doen dit van harte soos vir die Here en nie vir mense nie" (vs. 23). Aan die gemeente van Korinthe skrywe dieselfde Paulus: "Of julle dan eet of drink of enigiets doen, doen alles tot verheerliking van God" (I Kor. 10:31). Waar die burgers dus, indiwidueel of kollektief, buite of binne organisatoriese verband, in die wetenskap en die kuns, in die politiek en die huwelikslewe, in die staat en die sake-onderneming, ja, waar ookal, buig voor die gesag van God wat deur sy Woord heers, dáár breek iets van die koninkryk van God deur. So kry ons dus verskillende gestaltes van die koninkryk. Want die gehoorsaamheid aan God in die wetenskap is anders as die gehoorsaamheid in die kuns, en ánders in die staat as in die huwelikslewe. Nie dat die gehoorsaamheid sélf anders is nie - dié bly dieselfde - maar die Woord spreek die mens telkens anders aan, en daarop word telkens anders maar steeds in gehoorsaamheid, geantwoord.

Maar nou kom die burgers van die koninkryk by geleentheid in gehoorsaamheid aan die Skrifgeworde Woord - ook saam om na die verkondiging van daardie Woord - Koninkrykswoord! - te luister; daardeur gevoed en vir hulle dagtaak in die wêreld gesterk te word. Hulle samekoms verkry 'n vaste struktuur en orde en hulle word lede van die organisasie - so kry ons dan die kerk met sy lidmate. Daarom kan ons met reg sê: die kerk is die burgers van die koninkryk wat tot lof van die Koning en onder leiding van die ampte

(a) die seëninge van die Godsryk liturgies-kulties beleef en verkondig, en

(b) hulle met hiermee verbandhoudende sake besig hou.

Dit is duidelik dat die gedagte van die institutêre, dit wil sê die organisatoriese, in hierdie omskrywing van die kerk, 'n belangrike rol speel. Maar dan mag die kerk ook weer nie nét tot die kultiesinstitutêre beperk word nie. Die institutêre bestaan immers nie nét uit die kultiese nie. Daar is ook die didakties-institutêre (kategese), die pastoraal-institutêre (huisbesoek) en die diakonaal-institutêre (diens van barmhartigheid) wat eweseer tot die kerk gereken moet word.

Rondom die uitspraak: die kerk is teken van die koninkryk, kan die verhouding van die koninkryk en die kerk myns insiens verder die beste uitgewerk word. Die woord teken sal dan egter goed begryp moet word. Die teken wys natuurlik na die betekende saak heen; waarmee egter nie gesê word dat die teken self leeg is nie. 
Die aanduidende of die signifikatiewe aspek van die teken-begrip is nie die enigste wat ons kan onderskei nie. Daar is ook nog die deelnemende of die partisiperende aspek wat in berekening gebring moet word. Die teken is nie leeg nie, maar gevul, want soos die simbool deel het aan die gesimboliseerde, só het ook die teken ín sy heenwysing na die betekende saak, deel aan die betekende saak. Deel hê aan, en verband hou met die be-teken-de saak, impliseer dus duidelik dat laasgenoemde veel groter en heerliker is as die teken self, omdat dit daarmee nie saamval nie. En nou sê ons: die kerk is as aardse werklikheid teken - allereers - van die koninkryk. Die kerk wys heen na, maar het ook deel aan die koninkryk. Vanuit die heenwysende perspektief vestig ons die aandag op die volgende: die kerk is maar één gestalte van die ryk, daar is talle en talle ander gestaltes. Die Christelike huisgesin, die Christelike skool en -komitee, die Christelike kultuurvereniging, die Christelike staat, ens., - hulle almal is gestaltes van die koninkryk, en as sodanig nie kerk nie - ook nie, soos dikwels in die Gereformeerde teologie gedoen is, die kerk as organisme nie. Die aanwesigheid van 'n aantal kerklidmate op ' $n$ ouer-onderwyservereniging, maak dit nog nie kerk nie; net so $\min$ as wat 'n aantal skaakklublede wat rugby speel, van die rugbyklub 'n skaakklub maak nie. Die kerk is nie oral daar waar sy lidmate aanwesig is nie. Maar waar die burgers is, daar is die koninkryk. Daar is dus ' $n$ kerklike gestalte en nie-kerklike gestaltes van die Godsryk en eersgenoemde is nie heiliger as laasgenoemde nie.

Die kerk is maar één aspek van die Christelike lewe, daar is talle en talle ander aspekte. Die volheid van die Christelike lewe in die verskeidenheid van al sy openbaringe, is veel groter en heerliker as die kerklike aspek van die Christelike lewe. Daarom mag die lewe ook nie verkerklik word nie - wel verchristelik word, wat in feite presies dieselfde is as ver-koninklik. Die Christelike lewe is in die kerk dus slegs ten dele, in die koninkryk ten volle aanwesig. Verkerkliking sou ook op kerkisme neerkom. Wie kerk - of sý kerk alleen - gaan sien as die enigste gestalte van die koninkryk, oorwoeker die ander legitieme gestaltes van die ryk, vermink die ganse samelewing, en verarm die koninkryk. Die kerk het in sy boodskap maar één brandpunt waarheen alles wys, en dit is die koninkryk, en dan die koninkryk in al sy verskillende aardse gestaltes. Aan sy dissipels het Jesus dan ook nadruklik die opdrag gegee om - soos Hy self - die koninkryk te verkondig (Matt. 10:7,4 4:17) en dit is presies wat Paulus ook gedoen het. Hy het die koninkryk gepreek en aangaande die Here Jesus Christus onderrig gegee (Hand. 28:31, vgl. vs. 23). Maar onderrig aangaande Jesus is juis onderrig aan die koninkryk: in Hom heers God en in Hom is die mens aan die heerskappy van God gehoorsaam. In Hom is die koninkryk van God geopenbaar en in Hom het die koninkryk vir alle mense 'n werk- 
likheid geword. Wie dus deur die geloof in die opgestane Jesus, self deel aan die opstandigslewe kry, word 'n burger van die koninkryk. As die kerk bid - in gehoorsame opdrag van Christus - om die koms van die koninkryk, word daarin nie gevra dat die kerk die enigste gestalte van die koninkryk gemaak word nie, maar dat die koninkryk mag kom - óók in die kerk - sonder dat die kerk eers by name in die Onse Vader genoem word! Die kerk verkondig die boodskap van die ryk, dit wil sê, roep sy lidmate op om as burgers tekens van die koninkr'yk in die wêreld op te rig. En terwyl hulle met toewyding on oorgawe daaraan arbei, bid hulle dat die Koning self sy ryk sal laat kom. Dat Hý én húlle aan die koninkryk werk is juis sy bedoeling. Prediking van die koninkryk is dus nie nét nie, maar óók kcrkvormend, terwyl omgekeєrd, alle egte kerkvorming konkrete koninkryissprediking is. Maar dan is ook elke egte, dit wil sê Woordgebonde en -gehoorsame staatsvorming, verenigingsvorming, wetenskapsvorming, kunsvorming, ens., koninkryksprediking.

Vanuit die deelnemende perspektief wys ons op die feit dat die kerk, op grond van sy syn in Christus, voor God 'n status het, $n l$. dié van die koninkryk-op-die-wyse-van-die-kerk. Dat die status voortdurend ook waargemaak moet word, en so in 'n dinamiese proses van ontwikkeling - intensiewe verdieping en ekstensiewe uitbreiding - opgeneem is, doen geen tekort aan die realiteit van die status nie. In die kerk is die Godsryk aanwesig, en daar word sy boodskap gehoor en gevier, soos nêrens anders in die wêreld nie. Die lig wat die kerk versprei, is die lig van die koninkryk, en aan dié lig word die kerk self ook gemeet. In die kerk is die koninkryk op 'n kerklike wyse - gerealiseer. Daarom mag die kerk nie, as orgaan en resultaat van die aanwesige, hoewel in sy volheid nog komende koninkryk, geminag word nie. Klein mag die kuddetjie inderdaad wees, en tog het die Vader ' $n$ welbehae daarin gehad om aan hulle die koninkryk te gee (Luk. 12:32). Met toewyding en liefde sal aan die kerk gearbei moet word, maar dan steeds aan die kerk met die oog op die koninkryk, want eers in die lig van die koninkryk word die geheim van die kerk tot in sy diepste bestemming deursigtig. Die kerk wat die koninkryk uit sy gesigseinder verloor en aan homself begin arbei van sy eie grootheid en heerlikheid en mag droom, dié kerk het verwêreldlik en versaak sy roeping. In sy bestaan en handelinge, in sy diens en prediking moet die kerk die ryk aanwys en aanmeld, proklameer en demonstreer. Die ryk is die kritiese maatstaf waarmee die kerk homself - én alle ander gestaltes van die ryk - beoordeel. Wat daarvoor diensbaar is, is goed, wat nie diensbaar is nie, is nie goed nie. Juis die perspektief van die koninkryk bewaar die kerk daarvan om hom in homself terug te trek en alleen met sy eie religieuse belewinge besig te wees, dog dryf die kerk die wêreld in om intensief met wêreldse ordeninge en strukture besig te wees - maar dan op 'n kerklike wyse. Die 
koninkryk is geregtigheid en vrede en blydskap in die Heilige Gees, sê Paulus in Romeine 14:17, en die kerk sal dié boodskap nie mag verswyg nie. Self ingebed in die geheel van Gods verlossende handelinge met die wêreld, is die kerk geroep om op 'n kerklike wyse die strydende voorhoede van die Godsryk te vorm. Daarom veg die kerk met die swaard van die Woord en nie met die swaard van staal nie, met die dinamiet van die Gees en nie met die dinamiet van ontploffende bomme nie. Maar dan moet die kerk ook inderdaad daarmee veg, en 'n radikale Christelike maatskappykritiek as deel van sy taak verstaan. Die ryk van die Bose het ook sý tekens wat met betrekking tot die tekens van die Godsryk as anti-tekens gekwalifiseer moet word; dit wil immers die tekens van die koninkryk van hul inhoud beroof, dit wil teken en betekende saak uit hul intieme relasie uitlig, en die teken volkome verteken. Die ware teken word 'n valse teken; die ware kerk ' $n$ valse kerk, die ware staat ' $n$ valse staat, die ware gesin ' $n$ valse gesin. Juis daarteen is die kerk geroep om te veg. Waar dit ook al in die wêreld gebeur en deur wie dit ook al gedoen word, het die kerk sy profeties-waarskuwende taak te vervul.

Die kerk is egter ook in ander opsigte ' $n$ teken. Die kerk is teken van die kerk. Dat die kerk teken ook van homself is, wil sê dat die kerk wel kerk is, maar dat die kerk nog nie afgerond en voltooi is nie. Daar is ' $n$ dinamiese proses van kerkwording aan die gang en wel in die mate waarin die kerk al meer en meer aan die Woord gehoorsaam is. Die volheid van wat kerkwees impliseer, is nog nie gerealiseer nie. Daar is moontlikhede van kerkwees wat nog uitstaande is. Die kerk is nie self die volheid in wording nie, maar teken daarvan dit wil sê die kerk is deel van die volheid in wording. Dat die kerk as teken deursigtig moet wees, dit wil sê die betekende saak, naamlik die koninkryk, helder en duidelik sal moet weerspieël, maak van hom nie 'n irreële of onsigbare saak nie. Inteendeel. Om die koninkryk te laat sien, moet ook die kerk as teken sintuiglik waarneembaar wees. Daarom is die kerk na sy wese sigbaar. 'n Onsigbare kerk bestaan nie. Ook die tekens wat Jesus gedoen het, as vooruitgeworpe ligstrale van die nabygekome koninkryk (Mark. 3:22 e.v.) was sigbaar; vir almal waarneembaar - al het almal nie die betekenis daarvan verstaan nie. Soos ' $n$ onsigbare teken geen spraak het nie, het ' $n$ onsigbare kerk geen boodskap nie. Die kerk is teken van homself - talle wag nog in die eeue wat moet kom om tot die skare van feesvierendes in die kerk van Christus toegevoeg te word.

Maar die kerk is ten slotte ook teken van die wêreld. Die kerk bestaan nie buite die wêreld nie; die kerk is sélf ' $n$ wêreld. ' $n$ Stuk wêreld waarop God beslag gelê het en waar sy beslaglegging met vreugde en dankbaarheid aanvaar is. Daarom kan die kerk aan die 
wêreld verkondig dat hy die sin en die bestemming van die wêreld gesien en verstaan het: die koninkryk van God. Want wat is die koninkryk anders as die wêreld in sy betrokkenheid op God? Daar was immers 'n tyd - vóór die sonde - toe skepping en koninkryk sinonieme werklikhede was; soos dit eenmaal weer - ná die sonde - die geval sal wees. En soos daar vroeër geen teken nodig was nie, sal daar later ook geen teken meer nodig wees nie. Soos daar in die begin geen kerk was nie, sal daar aan die einde ook geen kerk wees nie. Teken en betekende saak sal dan weer volkome identies wees. Dán het die koninkryk tot sy volheid gekom en die skepping sy eindbestemming bereik - intussen kan ons die kerk as teken nie ontbeer nie. En die taak van die kerk in die tussentyd? Hy moet vashou aan die wêreld, anders verloor hy die koninkryk; maar hy moet ook vashou aan die koninkryk, sy boodskap verkondig en sy heil vier, anders verloor hy die wêreld. En 'n kerk wat die wêreld en die koninkryk verloor het, het alles verloor. 